\title{
Influences of Coal Ash Leachates and Emergent Macrophytes on Water Quality in Wetland Microcosms
}

\author{
Leif H. Olson • John C. Misenheimer • \\ Clay M. Nelson • Karen D. Bradham • \\ Curtis J. Richardson
}

Received: 10 May 2017 / Accepted: 3 August 2017

(C) Springer International Publishing AG 2017

\begin{abstract}
The storage of coal combustion residue (CCR) in surface water impoundments may have an impact on nearby water quality and aquatic ecosystems. CCR contains leachable trace elements that can enter nearby waters through spills and monitored discharge. It is important, therefore, to understand their environmental fate in affected systems. This experiment examined trace element leachability into freshwater from fly ash (FA), the most common form of CCR. The effects on water quality of FA derived from both high and low sulfur coal sources as well as the influences of two different emergent macrophytes, Juncus effusus and Eleocharis quadrangulata, were evaluated in wetland microcosms. FA leachate dosings increased water electric conductivity (EC), altered $\mathrm{pH}$, and, most notably, elevated the concentrations of boron (B), molybdenum
\end{abstract}

Electronic supplementary material The online version of this article (doi:10.1007/s11270-017-3520-4) contains supplementary material, which is available to authorized users.

L. H. Olson $(\bowtie) \cdot$ C. J. Richardson

Nicholas School of the Environment, Duke University Wetland Center, Box 9033, Duke University, Durham, NC 27708, USA

e-mail: leifolson89@gmail.com

J. C. Misenheimer

Oak Ridge Institute for Science and Education, Research Triangle Park, NC 27709, USA

C. M. Nelson · K. D. Bradham

Public Health Chemistry Branch, Exposure Methods and

Measurements Division, National Exposure Research Laboratory,

Office of Research and Development, U.S. Environmental

Protection Agency, Research Triangle Park, NC 27709, USA
(Mo), and manganese (Mn). The presence of either macrophyte species helped reduce elevated EC, and B, $\mathrm{Mo}$, and $\mathrm{Mn}$ concentrations over time, relative to microcosms containing no plants. B and Mo appeared to bioaccumulate in the plant tissue from the water when elevated by FA dosing, while Mn was not higher in plants dosed with FA leachates. The results of this study indicate that emergent macrophytes could help ameliorate downstream water contamination from CCR storage facilities and could potentially be utilized in wetland filtration systems to treat CCR wastewater before discharge. Additionally, measuring elevated B and Mo in aquatic plants may have potential as a monitoring tool for downstream CCR contamination.

Keywords Coal combustion residues · Fly ash . Phytoremediation · Juncus effusus · Eleocharis quadrangulata . Wetland · Boron · Manganese · Molybdenum

\section{Introduction}

Increasing global electricity demand has led to expanding and diversifying energy sources, but coal is still the leading source of energy in the world, providing $40 \%$ of the heat and electricity production (WCA 2014). Advances in coal burning technology have led to reduced emissions from power plants, but have been accompanied by increased production and shifts in the chemical composition of coal combustion residue (CCR), commonly referred to as "coal ash" 
(Dellantonio et al. 2010). CCR can contain a variety of leachable, potentially toxic trace elements including aluminum (Al), iron $(\mathrm{Fe})$, arsenic $(\mathrm{As})$, boron $(\mathrm{B})$, cadmium $(\mathrm{Cd})$, chromium $(\mathrm{Cr})$, copper $(\mathrm{Cu})$, lead $(\mathrm{Pb})$, manganese $(\mathrm{Mn})$, mercury $(\mathrm{Hg})$, molybdenum (Mo), selenium (Se), and thallium (Tl), among others (Izquierdo and Querol 2012; Cherry and Guthrie 1977).

Surface water impoundments, also called "lagoons," are commonly used to store CCR. This method of storage has come under scrutiny in the USA following impoundment failures in Kingston, TN, and Eden, NC, that contaminated the Emory River (Ruhl et al. 2010) and Dan River (Lemly 2015), respectively. Aside from large spills, coal ash lagoons can cause contamination through leachate discharges into surface waters (Ruhl et al. 2012; Rowe et al. 1996) and the leaching of trace elements from unlined lagoons into groundwater aquifers (Carlson and Adriano 1993).

It is important to understand the influence of CCR disposal on ecological function and human health because of the widespread use of coal combustion in the world. Studies suggest that CCR and their leachates pose a risk to aquatic wildlife (Rowe et al. 2002; Lemly and Skorupa 2012), and trace element concentrations measured from lagoon outfalls in the USA are often above drinking water guidelines (Ruhl et al. 2012). CCR leachates contain complex mixtures of potential contaminants that migrate through a variety of environmental matrices including water, soil, plant, and animal tissues and likely behave differently in each.

The interaction of CCR leachates with wetland ecosystems is of interest, because wetlands tend to be sinks and transformers of contaminants, filtering water passing between lakes, rivers, and aquifers (Richardson 1989; Mitsch and Gosselink 2015). Emergent macrophytes help facilitate this filtration by slowing the flow of water and wind, sequestering chemicals, releasing oxygen in the rhizosphere, and providing algal and microbial habitat (Vymazal 2013; Bhatia and Goyal 2014; Preussler et al. 2015; Sundberg-Jones and Hassan 2007). Constructed wetland treatment systems (CWTS) containing emergent macrophytes can potentially be effective for treating CCR wastewater, though the literature on this topic is limited (Ye et al. 2001a, b; Dorman et al. 2009). The treatment of coal ash lagoon leachate with CWTS before discharge and the presence of natural wetlands and emergent macrophytes downriver from discharges could improve the quality of nearby water bodies.
A greenhouse study was performed to examine how leachable trace elements from fly ash (FA), the lightest and most abundant form of CCR (Dellantonio et al. 2010), accumulate in wetland microcosms. Microcosms with and without emergent macrophytes were compared to evaluate the influence of these plants on water quality, as well as their bioaccumulation potential. Additionally, FA from high sulfur coals and low sulfur coals were compared, which tend to have different chemical compositions that can be traced back to their origins. High sulfur coal is harvested from areas that were saltwater environments at the time of the coal's formation, while low sulfur coal comes from areas that were freshwater environments during the coal's formation (Chou 2012).

This study sheds light on the chemical influences and mobility of trace elements from high and low sulfur FA leachates on aquatic wetland systems, as well as the potential of emergent macrophytes to ameliorate aquatic CCR contamination, either naturally or in engineered systems. The focus of the study was to determine how well emergent macrophytes reduced water contamination, and if their aboveground vegetation accumulated the analyzed trace elements, which would have implications for food web accumulation and biomonitoring.

\section{Materials and Methods}

\subsection{Materials}

Soil was acquired from Sands and Soils (Durham, NC) and upon arrival at the greenhouse was steam pasteurized and homogenized. The soil texture was sand $64.6 \%$, clay $9.3 \%$, and silt $26.1 \%$.

Juvenile root plugs of Juncus effusus and Eleocharis quadrangulata were acquired from Mellow Marsh Farms (Siler City, NC). The species were chosen, because they are native and non-invasive in North Carolina wetlands, demonstrate radial oxygen loss which influences ion transformations around the plant roots (Michaud and Richardson 1989), and were previously found growing voluntarily in Tennessee Valley Authority constructed wetlands treating coal ash pond effluent (Brodie 1990), suggesting a tolerance to CCR.

\subsection{Microcosm Experiment}

Soil was placed in $18.9 \mathrm{~L}$ high-density polyethylene (HDPE) buckets to a depth of $15 \pm 2 \mathrm{~cm}$. Nine buckets 
were planted with five $J$. effusus root plugs, nine buckets were planted with five $E$. quadrangulata root plugs, and nine buckets contained no macrophytes. The microcosms were watered daily with reverse osmosis (RO) water for 77 days; then, the buckets were flooded to create a simulated wetland habitat by filling each bucket with RO water until the water level was within $8 \mathrm{~cm}$ of the bucket's rim. For the remainder of the experiment, microcosms were watered one to two times a week, maintaining the standing water depth at $8 \mathrm{~cm}$ below the bucket's rim.

\subsection{Leachate Production}

FA from a high sulfur coal and a low sulfur coal were acquired from two southern Appalachian power plants and examined separately. Following the EPA Method 1316, moisture content of the FA was estimated and leachates were made in a 10:1 $\mathrm{m} / \mathrm{v}$ ratio. For each type of FA, a 3.8-L polypropylene (PP) bottle was filled with the equivalent of $300 \mathrm{~g}$ of dry FA and $3 \mathrm{~L}$ of deionized (DI) water, corrected for moisture content. The bottles were then mixed on a reciprocal shaker bath at $180 \mathrm{rpm}$ for $24 \pm 2 \mathrm{~h}$. The contents were then poured through a 45- $\mu \mathrm{m}$ Whatman nylon membrane filter laid on top of a Millipore plastic filter, which was emptied into a glass filter flask. The filtered leachate of each FA was poured into a 20-L HPDE bucket and stored at $4{ }^{\circ} \mathrm{C}$ until experimental use. Leachates were filtered to simulate retention pond outfall water and to reduce variation between dosings.

\subsection{Dosing Procedures}

For each microcosm, a 250-mL HDPE bottle was labeled and subsequently filled with high sulfur leachate, low sulfur leachate, or RO water during dosing procedures. The composite leachate buckets were each mixed for $10 \mathrm{~min}$ with a wooden stirring rod before collecting $250 \mathrm{~mL}$ aliquots for dosing.

A total of 27 microcosms were created: nine received high sulfur leachate, nine received low sulfur leachate, and nine received $\mathrm{RO}$ water. Of the nine microcosms for each treatment, three contained $J$. effusus, three contained E. quadrangulata, and three contained no macrophytes.

Two separate dosings were performed for every microcosm variable. For the first dosing, 25 days after the microcosms were flooded, $1 \mathrm{~L}$ was applied in four increments of $250 \mathrm{~mL}$ over $16 \mathrm{~h}$. For the second dosing, 61 days after flooding, $2.5 \mathrm{~L}$ was applied in 10 increments of $250 \mathrm{~mL}$ over 10 days. These dosing regimens were used to simulate a variety of rates of leachate input into the wetland systems.

\subsection{Plant Growth Measurements}

The heights of the five tallest individual plants and the stem density of each microcosm were measured once a week. Average height growth and stem density were calculated by summing the values for a microcosm in a week then subtracting the previous week's value from the current number. The dry biomass of macrophytes in each microcosm was measured after harvesting them at the end of the experiment. Growth measurements were used to assess toxicity from leachates.

\subsection{Water Measurements}

The electrical conductivity (EC) and $\mathrm{pH}$ of the water in each microcosm was measured once a week. EC was measured using an Orion model 122 conductivity meter and Orion 012210 conductivity cell. The frequency of EC measurements was increased to once every 3 days during the second dose. The EC probe was checked in a $\mathrm{KCl}$ solution, and the reading was compared to the expected value of $1.413 \mathrm{mS} / \mathrm{cm}$. Readings from the reference solution were within $5 \%$ of the expected value for each set of measurements, with one exception in which the reading deviated $7.01 \%$ from expected. A Hannah Instruments (HI) 98121 combo pH and ORP probe was used to measure $\mathrm{pH}$ once a week. The probe was calibrated in a $\mathrm{pH} 4$ and 7 reference solution at least once every 10 days and usually before each set of measurements. Readings from $\mathrm{pH}$ reference solutions were within $5 \%$ of the expected value before each set of measurements was taken.

Water samples were collected before each dosing, after each dosing and before harvesting the macrophytes by pipetting water from several centimeters below the surface in the middle of each microcosm into $50-\mathrm{mL}$ HDPE centrifuge tubes, then stored at $4{ }^{\circ} \mathrm{C}$ prior to analysis; the water samples were filtered through a 45- $\mu \mathrm{m}$ Whatman nylon membrane filter.

An initial qualitative screening of 30 elements was performed on water samples collected after each dosing (Online Resource 1). B, Mo, and Mn concentrations 
were observed to increase the most between different treatments after dosing and were chosen for further examination. In the analyzed samples, other elements associated with CCRs including $\mathrm{As}, \mathrm{Se}, \mathrm{Cr}$, and $\mathrm{Tl}$ (Izquierdo and Querol 2012; Cherry and Guthrie 1977) were not notably increased by dosings and were not further examined.

It is important to note that FAs are highly variable in their chemical composition, and only two different FA samples were tested in this study. The elements observed in this study only reflect leachable elements from the specific batches of FA used according to the methodology of this study and should not be used to generalize about FA and CCRs as a whole, especially since in practice, they are stored in dynamic systems influenced by biotic and abiotic factors not addressed in this study.

\subsection{Soil and Plant Sampling}

Soil samples were collected from each microcosm right before the first dose, 7 days after the first dose, and at the end of the experiment. Wide mouth straws were cut at an angle then used to collect three $5-\mathrm{cm}$ cores that were combined into a composite sample for each microcosm. Soil samples were stored at $4{ }^{\circ} \mathrm{C}$ prior to analysis; subsamples were dried at $40{ }^{\circ} \mathrm{C}$ for $72 \pm 4 \mathrm{~h}$ then homogenized with an agate mortar and pestle that was rinsed with $0.5 \mathrm{~N} \mathrm{HCl}$ and DI water in between samples.

Plant material was harvested at the end of the experiment, corresponding to 90 days after the first dosing and 54 days after the second. Harvested plant material was rinsed with tap water, then rinsed with a Tween 20 solution and DI water three times, following Hansen et al. (2013). They were then placed in paper bags and dried at $60{ }^{\circ} \mathrm{C}$ for 7 days. Roots and stems were separated with ceramic scissors, then separately homogenized using a Planetary Mill Ball Grinder (PQ-N04, Across International). Agate grinding containers and balls were rinsed with $0.5 \mathrm{~N} \mathrm{HCL}$ and DI water in between samples to prevent cross-contamination.

\subsection{Elemental Analysis}

Soil samples of $0.4-0.5 \mathrm{~g}$ were digested by microwaveassisted acid digestion (Mars 6, CEM Corporation) in Teflon tubes with $10 \mathrm{~mL}$ high purity $\mathrm{HNO}_{3}$
(PlasmaPure) at $175{ }^{\circ} \mathrm{C}$ with a ramp time of $5.5 \mathrm{~min}$ and hold time of $4.5 \mathrm{~min}$. Plant stem and root samples of $0.5-0.6 \mathrm{~g}$ were predigested overnight with $5 \mathrm{~mL}$ of high purity $\mathrm{HNO}_{3}$ then microwave-assisted acid digested at $200{ }^{\circ} \mathrm{C}$ with a ramp time of $25 \mathrm{~min}$ and hold time of $10 \mathrm{~min}$. Both types of FA were also digested as $0.4-0.5 \mathrm{~g}$ samples in $10 \mathrm{~mL}$ of high purity $\mathrm{HNO}_{3}$ at the same time as the plant tissue samples. After digestion, all samples were decanted into HDPE centrifuge tubes and diluted to $50 \mathrm{~mL}$ with DI water.

Soil, plant, and FA digestates were analyzed by inductively coupled plasma optical emission spectroscopy (iCAP 6500 Duo, Thermo Scientific). Water and FA leachate samples were analyzed by inductively coupled plasma mass spectroscopy (XSeries II, Thermo Scientific). All samples were diluted to a $2 \%$ nitric acid $(v / v)$ solution before analysis.

QA/QC samples were run with sample analyses and included appropriately matched NIST standard reference materials (SRMs) and matrix spike samples. Method reporting limits (MRLs) were also determined for each matrix and element. Sample values associated with SRM or matrix spike recoveries that exceeded $25 \%$ of the expected value were flagged as estimates, as were values that fell below the MRL (Online Resource 2).

\subsection{Data Analysis}

Statistical analysis was performed with R 3.2.2 (R. Core Team 2015) utilizing the plyr (Wickham 2001) and PMCMR (Pohlert 2014) packages. Changes in plant growth, EC, and $\mathrm{pH}$ over time were analyzed using linear regression models. Data was checked for normality and homodescaticity. When the assumptions were violated, generalized linear models were used.

Trace element concentrations in water, soil, and plant tissues were analyzed with the non-parametric KruskalWallis comparison of means test. Significant differences between individual means were determined by post hoc analysis using the Dunn, Conover, and Nemenyi multiple comparisons tests from the PMCMR package (Pohlert 2014).

\subsection{Plant Elemental Uptake Analysis}

For treatments that significantly increased the water concentration of a given trace element, a bioconcentration factor $(\mathrm{BCF})$ and a translocation factor $(\mathrm{TF})$ were 
calculated. According to Zayed et al. (1998), BCFs were calculated as follows:

$\mathrm{BCF}=\frac{[\text { Concentration of element in stems or roots }]}{[\text { Concentration element in water }]}$

TFs were calculated as follows:

$\mathrm{TF}=\frac{[\text { Concentration of element in stems }]}{[\text { Concentration element in roots }]}$

\section{Results and Discussion}

\subsection{Trace Element Leachability from Fly Ash}

High sulfur FA contained more B, Mn, and Mo than low sulfur FA, but only Mo was more leachable from high sulfur FA on a percent basis (Table 1). Mn was not detectable in the high sulfur leachate, while B, despite being more leachable from low sulfur FA, had a higher concentration in high sulfur leachate due to the much greater B content in the high sulfur FA.

\subsection{Water Physicochemical Properties}

The water EC increased in microcosms dosed with FA leachates, while EC changed little when dosed with RO water (Fig. 1). For both dosings, EC increases were significantly higher for high sulfur leachates than the other two treatments $(p<0.01)$ and significantly higher for low sulfur leachates than controls $(p<0.01)$. After the completion of each dosing, the decline in water EC was significantly lower when either species of macrophyte was present $(p<0.01)$.

$J$. effusus microcosms reduced water EC by 32 and $49 \%$ from peak concentrations after the first and second low sulfur doses and by 51 and $53 \%$ after first and second high sulfur doses, respectively. E. quadrangulata microcosms reduced water EC by 27 and $49 \%$ from peak concentrations after the first and second low sulfur doses and by 39 and $48 \%$ after first and second high sulfur dose, respectively. In contrast, reductions in EC in nonplanted microcosms receiving leachate ranged from -3 to $9.3 \%$.

The changes in $\mathrm{pH}$ differed based on leachate type, with high sulfur leachate significantly increasing the $\mathrm{pH}$ $(p<0.01)$ and low sulfur leachate significantly reducing the $\mathrm{pH}$ relative to $\mathrm{RO}$ water $(p<0.01)$. Non-planted
Table 1 Concentrations of leachable elements from fly ash extractions

\begin{tabular}{|c|c|c|c|c|c|c|}
\hline \multirow[t]{2}{*}{ Element } & \multicolumn{2}{|c|}{$\begin{array}{l}\text { Acid extractable } \\
(\mathrm{mg} / \mathrm{L})\end{array}$} & \multicolumn{2}{|c|}{$\begin{array}{l}\text { Water leachable } \\
(\mathrm{mg} / \mathrm{L})\end{array}$} & \multicolumn{2}{|c|}{ \% Leachable } \\
\hline & $\begin{array}{l}\text { Low } \\
\text { sulfur }\end{array}$ & $\begin{array}{l}\text { High } \\
\text { sulfur }\end{array}$ & $\begin{array}{l}\text { Low } \\
\text { sulfur }\end{array}$ & $\begin{array}{l}\text { High } \\
\text { sulfur }\end{array}$ & $\begin{array}{l}\text { Low } \\
\text { sulfur }\end{array}$ & $\begin{array}{l}\text { High } \\
\text { sulfur }\end{array}$ \\
\hline B & 58 & 330 & 2.25 & 8.53 & 3.89 & 2.59 \\
\hline $\mathrm{Mn}$ & 38 & 122 & 0.16 & 0 & 0.42 & 0 \\
\hline Mo & 14 & 50 & 0.46 & 4.01 & 3.31 & 8.07 \\
\hline
\end{tabular}

Acid extractable values are from nitric acid microwave digestions and water leachable values are from DI water leached for $24 \mathrm{~h}$ in a shaker bath and filtered. Percent leachable elements are shown in the right two columns $=([$ Leachate $] /[$ Digestate $]) \times 100(n=3)$

microcosms after the second dose had the highest mean $\mathrm{pH}$ of 8.0, while E. quadrangulata microcosms after the second dose had the lowest mean $\mathrm{pH}$ of 4.7 (Online Resource 3). There was not a significant difference between the $\mathrm{pH}$ changes in water with and without macrophytes, but every set of treatments and species ended with a $\mathrm{pH}$ closer to neutral than at their maximum perturbation.

Wetlands, both natural and constructed, receiving wastewater, have been shown to reduce EC and stabilize pH values towards neutral (Sasaki et al. 2003; Maine et al. 2009). In this study, EC reductions appear to be facilitated by the presence of emergent macrophytes, while the $\mathrm{pH}$ stabilization was not significantly related to their presence. EC has a linear relationship with ionic strength (Griffin and Jurinak 1973), which measures the quantity and degree of charge of chemical species in solution. The increase in EC with leachate dosings was likely a result of the input of soluble ions from the FA leachates, and many of these chemical species were directly or indirectly removed from the water column by the macrophytes as shown in Sect. 3.3.

\subsection{Elemental Fates}

\subsubsection{Boron}

The mean peak B concentrations in water receiving high sulfur leachate, low sulfur leachate, and RO water were 3915,1024 , and $32 \mu \mathrm{g} / \mathrm{L}$, respectively. Boron is one the most mobile trace elements in FA, and its leachability is generally not $\mathrm{pH}$ dependent (Izquierdo and Querol 2012), so its abundance in both leachates is expected. There were no significant differences in B soil 
Control (RO Water)

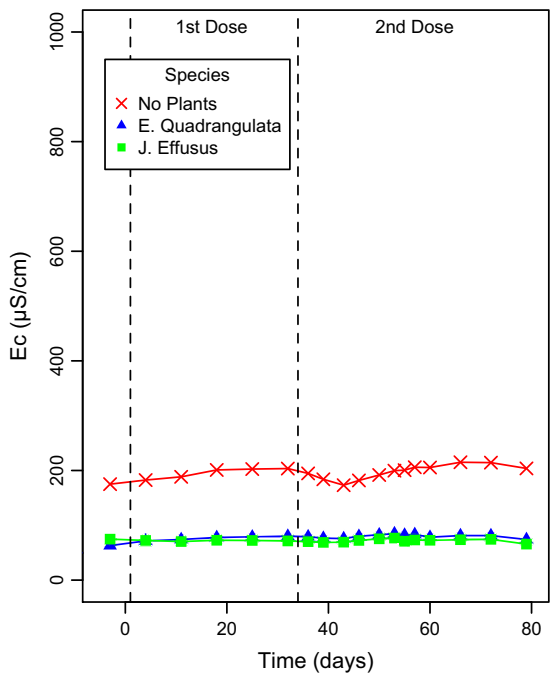

Fig. 1 Mean electric conductivity over time for microcosm water dosed with RO water (left), low sulfur fly ash leachate (center), and high sulfur fly ash leachate (right). Vertical dashed lines represent when dosings occurred. $Y$-axis values are the same for concentrations between treatments, and values were mostly below the MRL.

After dosing began, at days 10, 32, 46, and 89, water B concentrations were significantly higher in microcosms dosed with high sulfur leachates than with low sulfur leachates $(p<0.05)$ and RO water $(p<0.01)$ and significantly higher with low sulfur leachates than with RO water $(p<0.05)$ (Table 2$)$.

There was not a significant difference in B water concentrations based on plant type or presence after dosings; however, when either species of plant was present, $\mathrm{B}$ reduction ranged from 44.8 to $57 \%$, and when plants were not present, $\mathrm{B}$ reduction ranged from 8.4 to $15.7 \%$. In addition to higher B removal rates with plants present, macrophytes growing in water dosed with high sulfur leachates had significantly more B in their tissue than macrophytes growing in low sulfur leachate $(p<0.05)$ or RO water $(p<0.01)$ (Fig. 2).

Higher water concentrations of B were correlated with higher plant tissue concentrations, suggesting that the macrophytes sequestered B from the FA leachate. J. effusus stored significantly more B than $E$. quadrangulata $(p<0.01)$ and stems had significantly more B than roots $(p<0.01)$ (Fig. 2). Additionally, J. effusus had higher BCFs and both species' TFs were above one, indicating higher sequestrations in stems (Table 3).
Low Sulfur

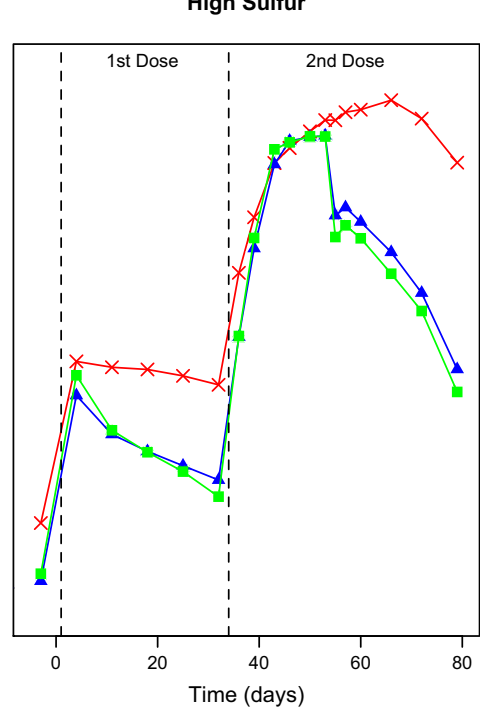

all three $(n=3)$. The initial measurements were taken 22 days after the microcosms were flooded, so the higher initial EC in unplanted microcosms suggests that both macrophyte species helped reduce EC before the dosings occurred as well as after

\subsubsection{Molybdenum}

The mean peak Mo concentrations in water receiving high sulfur leachate, low sulfur leachate, and RO water were 1032,43 , and $1 \mu \mathrm{g} / \mathrm{L}$, respectively. Molybdenum is highly leachable from FA and tends to be more mobile at higher pHs (Izquierdo and Querol 2012). Our research corroborates this observation, as microcosms receiving high sulfur leachates had increased $\mathrm{pH}$ and elevated Mo concentrations, while microcosms receiving low sulfur leachate had decreased $\mathrm{pH}$ and minimal Mo increases (Table 2). There were no significant differences in Mo soil concentrations between treatments, and values were mostly below the MRL.

At days 10,32, 46, and 89, water Mo concentrations were significantly higher in microcosms dosed with high sulfur leachates than with low sulfur leachates $(p<0.05)$ and RO water $(p<0.01)$.

At day 46, after the second dosing occurred, water Mo concentrations were significantly higher with low sulfur leachates than with RO water $(p<0.05)$.

There was not a significant difference in Mo water concentrations based on plant type or presence after dosing; however, when either species of plant was present, Mo reduction ranged from 85.7 to $95.5 \%$, and when plants were not present, Mo reduction ranged from 69.5 
Table 2 Mean concentrations (Conc.) and reductions (Red.) of trace elements in the water column after experimental dosings, based on treatment type and plant species present in microcosms

\begin{tabular}{|c|c|c|c|c|c|c|c|c|c|c|}
\hline \multirow[t]{2}{*}{ Dosing } & \multirow[t]{2}{*}{ Treatment } & \multicolumn{3}{|l|}{ Boron } & \multicolumn{3}{|c|}{ Molybdenum } & \multicolumn{3}{|c|}{ Manganese } \\
\hline & & $\begin{array}{l}\text { Conc. } \\
(\mu \mathrm{g} / \mathrm{L})\end{array}$ & $\begin{array}{l}\text { Red. } \\
(\mu \mathrm{g} / \mathrm{L})\end{array}$ & $\begin{array}{l}\text { Red. } \\
(\%)\end{array}$ & $\begin{array}{l}\text { Conc. } \\
(\mu \mathrm{g} / \mathrm{L})\end{array}$ & $\begin{array}{l}\text { Red. } \\
(\mu \mathrm{g} / \mathrm{L})\end{array}$ & $\begin{array}{l}\text { Red. } \\
(\%)\end{array}$ & $\begin{array}{l}\text { Conc. } \\
(\mu \mathrm{g} / \mathrm{L})\end{array}$ & $\begin{array}{l}\text { Red. } \\
(\mu \mathrm{g} / \mathrm{L})\end{array}$ & $\begin{array}{l}\text { Red. } \\
(\%)\end{array}$ \\
\hline \multirow{12}{*}{$\begin{array}{c}\text { Dose } 1 \text { (days } \\
10-32 \text { ) }\end{array}$} & High sulfur & & & & & & & & & \\
\hline & No plants & $1523.3 \mathrm{a}$ & 239.7 & 16 & $316.2 \mathrm{a}$ & 243.7 & 77 & 1175.3 & 909.7 & 77 \\
\hline & E. quadrangulata & $1546.7 \mathrm{a}$ & 692.3 & 45 & $291.0 \mathrm{a}$ & 249.6 & 86 & 4.7 & 4.3 & 91 \\
\hline & J. effusus & $1700.0 \mathrm{a}$ & 925.5 & 54 & $159.2 \mathrm{a}$ & 146.7 & 92 & 450.8 & 357.6 & 79 \\
\hline & Low sulfur & & & & & & & & & \\
\hline & No plants & $359.7 b$ & 41.2 & 12 & $14.3 \mathrm{~b}$ & 11.8 & 83 & 1602.3 & -47.0 & -3 \\
\hline & E. quadrangulata & $423.5 b$ & 210.5 & 50 & $7.7 \mathrm{~b}$ & 6.7 & 87 & 467.8 & 202.0 & 43 \\
\hline & J. effusus & $381.7 b$ & 179.1 & 47 & $1.3 \mathrm{~b}$ & 0.7 & 52 & 277.0 & 164.5 & 59 \\
\hline & Control & & & & & & & & & \\
\hline & No plants & $61.0 \mathrm{c}$ & -5.9 & -10 & $0.8 \mathrm{~b}$ & -1.0 & -128 & 717.9 & 443.2 & 62 \\
\hline & E. quadrangulata & $28.0 \mathrm{c}$ & 27.0 & 96 & $0.5 b$ & 0.6 & 123 & 3.2 & -0.3 & -9 \\
\hline & J. effusus & $33.5 \mathrm{c}$ & 9.5 & 28 & $0.5 \mathrm{~b}$ & -0.4 & -82 & 42.8 & 24.1 & 56 \\
\hline \multirow{12}{*}{$\begin{array}{c}\text { Dose } 2 \text { (days } \\
46-89)\end{array}$} & High sulfur & & & & & & & & & \\
\hline & No plants & $3918.7 \mathrm{a}$ & 428.7 & 11 & $1072.0 \mathrm{a}$ & 745.1 & 70 & $40.9 \mathrm{~b}$ & -9.3 & -23 \\
\hline & E. quadrangulata & $3891.7 \mathrm{a}$ & 2129.3 & 55 & $1101.3 \mathrm{a}$ & 990.5 & 90 & $0.4 \mathrm{~b}$ & -1.1 & -263 \\
\hline & J. effusus & $3935.0 \mathrm{a}$ & 2244.3 & 57 & $924.7 \mathrm{a}$ & 883.2 & 96 & $6.1 b$ & 6.0 & 99 \\
\hline & Low sulfur & & & & & & & & & \\
\hline & No plants & $957.7 b$ & 80.9 & 8 & $73.7 b$ & 67.8 & 92 & $1869.7 \mathrm{a}$ & 88.0 & 5 \\
\hline & E. quadrangulata & $1117.7 b$ & 582.1 & 52 & $36.1 \mathrm{~b}$ & 34.4 & 96 & $1654.7 \mathrm{a}$ & 731.6 & 44 \\
\hline & J. effusus & $997.8 b$ & 508.0 & 51 & $20.6 b$ & 19.2 & 93 & $821.9 a$ & 124.2 & 15 \\
\hline & Control & & & & & & & & & \\
\hline & No plants & $51.3 \mathrm{c}$ & -16.6 & -32 & $1.2 \mathrm{c}$ & 0.2 & 19 & $12.9 \mathrm{~b}$ & 11.4 & 89 \\
\hline & E. quadrangulata & $21.1 \mathrm{c}$ & -1.5 & -7 & $0.7 \mathrm{c}$ & -0.3 & -44 & $7.4 \mathrm{~b}$ & 2.1 & 28 \\
\hline & J. effusus & $23.8 \mathrm{c}$ & -5.8 & -24 & $1.5 \mathrm{c}$ & 1.2 & 82 & $19.4 b$ & 7.4 & 38 \\
\hline
\end{tabular}

$\overline{\text { Reductions were calculated as absolutes }\left([i]_{\mathrm{o}}-[i]\right) \text { and percentages }\left(\left(\left([i]_{\mathrm{o}}-[i]\right) /[i]_{\mathrm{o}}\right) \times 100\right) \text {. Different letter codes indicate significant }}$ differences in total concentration between treatments $(p<0.05)(n=3)$

to $77.1 \%$. There was also significantly more Mo in the plant tissue of macrophytes growing in water dosed with high sulfur leachates than with low sulfur leachates $(p<0.01)$ or RO water $(p<0.01)$ (Fig. 2). J. effusus had higher BCFs than E. quadrangulata, and TFs for both species were less than one, indicating higher sequestration in the roots, though neither the differences between species types or organs were significant (Table 3).

\subsubsection{Manganese}

There were elevated background water Mn concentrations in all microcosm treatments before the dosings began, which declined throughout the experiment for all treatments except for low sulfur leachates. By the time of the second dosing, the mean Mn concentrations were 13 and $16 \mu \mathrm{g} / \mathrm{L}$ for RO water and high sulfur leachate treatments, respectively, and $1449 \mu \mathrm{g} / \mathrm{L}$ in low sulfur leachate treatments. Manganese has limited leachability from FA, and its mobility from FA particles is higher at lower pHs (Izquierdo and Querol 2012). Our research corroborates this observation as low sulfur leachate dosings reduced water $\mathrm{pH}$ and elevated $\mathrm{Mn}$ concentrations and high sulfur dosings increased $\mathrm{pH}$ and had a minimal effect on Mn concentrations. There were no significant differences in Mn soil concentrations between treatments. 

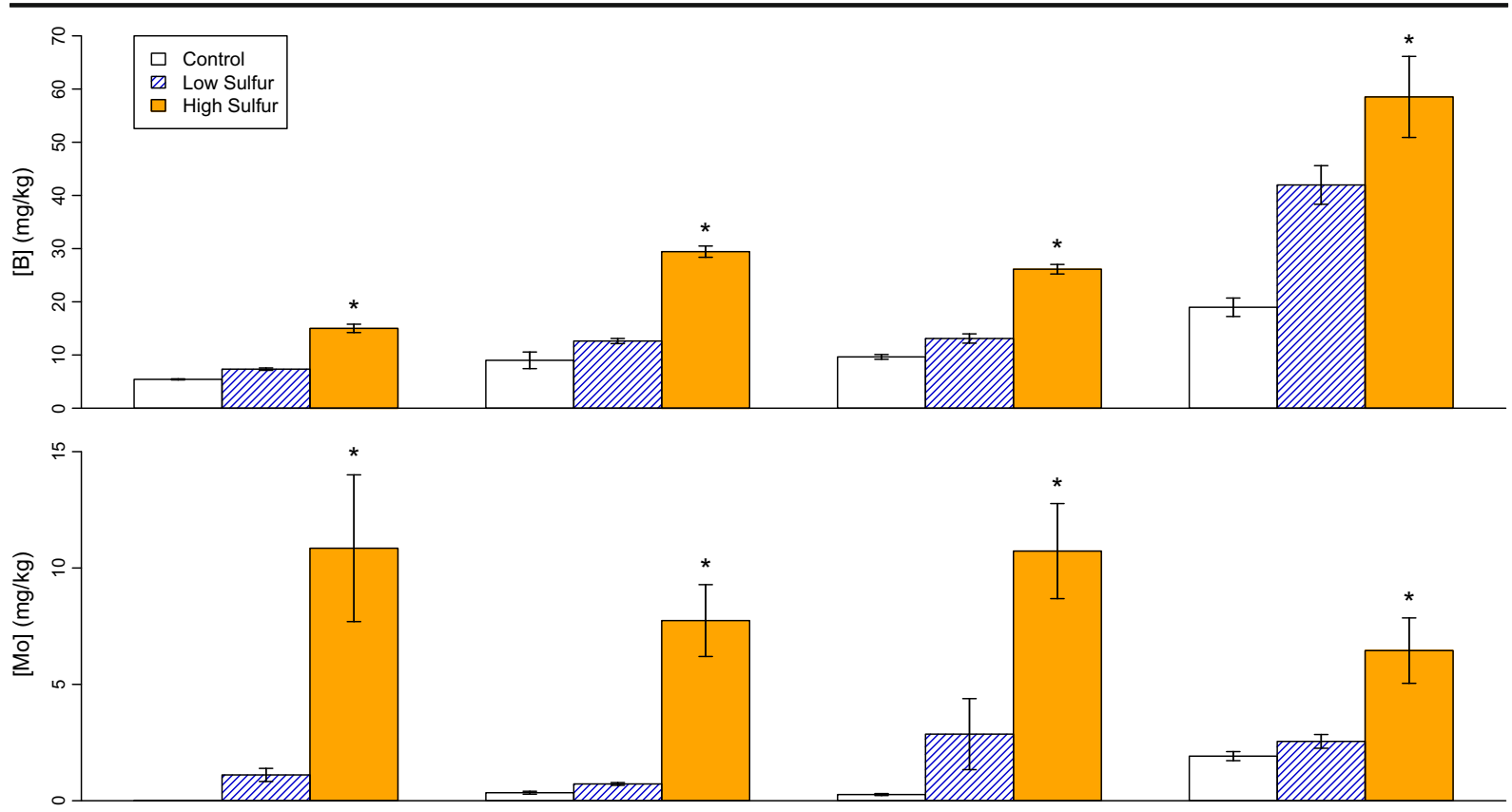

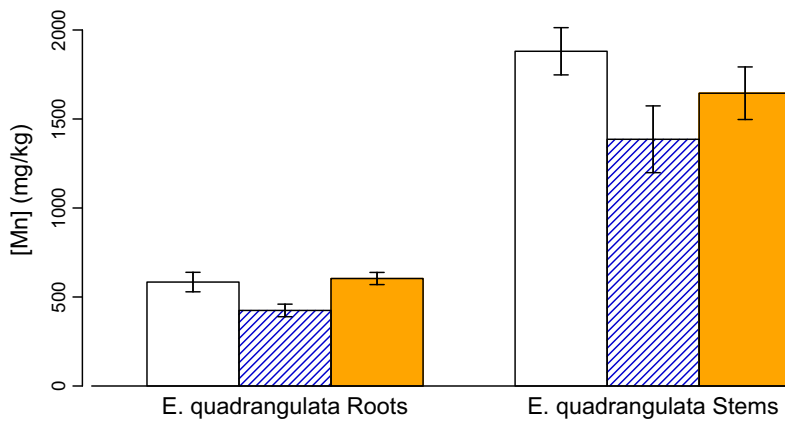

Fig. 2 Final plant dry weight tissue concentrations of boron, molybdenum, and manganese (top to bottom), in the roots and stems of E. quadrangulata and J. effusus (left to right), growing in microcosms dosed with high sulfur fly ash leachate (solid bars),
The low sulfur leachate's Mn concentration $(0.16 \mathrm{mg} / \mathrm{L})$ was lower than the water $\mathrm{Mn}$ concentration in microcosms receiving low sulfur leachates following either dosing $(0.28-1.9 \mathrm{mg} / \mathrm{L})$. This suggests that the increase in Mn did not come directly from the leachate and may have been due to other interactions. Unlike microcosms receiving high sulfur leachate and $\mathrm{RO}$ water, those receiving low sulfur leachate had acidic water. The lower $\mathrm{pH}$ of these microcosms' water was likely solubilized $\mathrm{Mn}$ from the submerged soil.

After the second dosing, at days 46 and 89, water Mn concentrations were significantly higher in microcosms receiving low sulfur leachate than those receiving high sulfur leachate $(p<0.01)$ or RO water $(p<0.05)$ (Table 2). At days 0 and 10, microcosms planted with
$J$. effusus $(p<0.05)$ and E. quadrangulata $(p<0.01)$ had significantly lower water Mn concentrations than unplanted microcosms, and E. quadrangulata microcosms were also significantly lower than unplanted ones at day $32(p<0.05)$.

E. quadrangulata had significantly more $\mathrm{Mn}$ in its tissue than J. effusus ( $p<0.05$ ), but $J$. effusus had higher Mn BCFs (Table 3). Plant stems stored significantly more Mn than roots $(p<0.01)$, and correspondingly, both species TFs were greater than one (Table 3 ). However, there was not a significant difference in Mn plant content between the treatments.

Soil concentrations of $\mathrm{Mn}$ ranged from 125 to $260 \mathrm{mg} / \mathrm{kg}$ with a mean of $181 \mathrm{mg} / \mathrm{kg}$, while the final plant tissue Mn concentrations ranged from 337 to 
Table 3 Bioconcentration factors (BCF) and translocation factors (TF) of trace elements in plant roots and stems for treatments that resulted in significant water increases from the control (Table 2)

\begin{tabular}{|c|c|c|c|c|}
\hline \multirow[t]{2}{*}{ Element } & \multirow[t]{2}{*}{ Treatment } & \multicolumn{2}{|c|}{ BCF $([$ Plant $] /[$ Water $]$} & \multirow{2}{*}{$\begin{array}{l}\text { TF }([\text { Stems }] / \\
[\text { Roots }])\end{array}$} \\
\hline & & Roots & Stems & \\
\hline \multirow[t]{6}{*}{$\mathrm{B}$} & High sulfur & & & \\
\hline & E. quadrangulata & 8.5 & 16.7 & 1.96 \\
\hline & J. effusus & 15.5 & 34.6 & 2.24 \\
\hline & Low sulfur & & & \\
\hline & E. quadrangulata & 13.7 & 23.6 & 1.72 \\
\hline & J. effusus & 26.8 & 85.7 & 3.20 \\
\hline \multirow[t]{3}{*}{ Mo } & High sulfur & & & \\
\hline & E. quadrangulata & 97.9 & 69.8 & 0.71 \\
\hline & J. effusus & 258.8 & 155.6 & 0.60 \\
\hline \multirow[t]{3}{*}{$\mathrm{Mn}$} & Low sulfur & & & \\
\hline & E. quadrangulata & 459.9 & 1501.5 & 3.27 \\
\hline & J. effusus & 568.7 & 1810.6 & 3.18 \\
\hline
\end{tabular}

$\mathrm{BCF}=[$ Plant tissue $] /[$ Water $]$, $\mathrm{TF}=[$ Stems $] /[$ Roots $]$ emergent macrophytes tend to be tolerant to inorganic pollutants (Bhatia and Goyal 2014) and that these species have previously been found to grow in wetlands treating coal ash wastewater, so the lack of observed toxicity is not surprising.

Toxicity from CCR leachates can be a concern for more sensitive organisms (Rowe 2014; Rowe et al. 1996, 2002), so the reduction of inorganic pollutants from CCR wastewater discharged into aquatic habitats is important. The demonstrated tolerance of emergent macrophytes and their ability to ameliorate water contamination in this study indicate that they could be effective for treating CCR leachate. This corroborates previous studies on CWTS treating CCR lagoon effluent (Ye et al. 2001a, b; Dorman et al. 2009) as well as B (Turker et al. 2013), Mn (Hallberg and Johnson 2005; Batty et al. 2008), and Mo (Lian et al. 2013) individually.

\section{Conclusions}

This study sought to examine the effects of high sulfur and low sulfur FA leachates and emergent macrophytes on water quality in a microcosm setting and found that both types of leachate changed a variety of water quality characteristics while the presence of macrophytes reduced these perturbations.

High sulfur FA leachates significantly increased water $\mathrm{pH}, \mathrm{EC}$, and $\mathrm{B}$ and Mo concentrations while low sulfur FA leachates significantly increased water EC, B, 
and $\mathrm{Mn}$ concentrations and decreased the $\mathrm{pH}$. The presence of $J$. effusus or E. quadrangulata reduced water EC and trace element concentrations after being elevated by leachates.

The plants did not show toxicity symptoms from the dosings, and there was generally not a significant difference between the two species' influences on water quality, but $J$. effusus had higher BCFs for all elements analyzed. Elemental analysis of both species of macrophytes indicated that they accumulated higher concentrations of B and Mo in their tissues when water concentrations were higher, while Mn did not appear to be accumulated in plant tissue from the contaminated water.

The varying environmental partitioning of the elements observed in this study emphasizes that when dealing with complex mixture contaminants like CCR, the combined behavior of its constituents must be accounted for. For example, elevated B and Mo concentrations in downstream plant tissue could be indicative of upstream CCR pollution while Mn may not be an effective indicator. After CCR spills, the contamination can quickly move downriver and may not appear in the surface water after a short period of time, when it may still be stored in other matrices, especially aquatic plants.

The emergent macrophytes were tolerant to CCR leachates and effective at water decontamination. This supports previous research suggesting that CWTS can be an effective tool for reducing the contaminant load from CCR impoundment discharges. The research on this topic is limited, however, and further studies should investigate how different emergent macrophyte species and treatment wetland designs perform with leachates from a variety of different CCR sources.

The volume of stored CCRs is immense and has the potential to affect nearby water quality when stored in surface impoundments. Therefore, understanding and managing the influences of CCRs on water chemistry and tracing their influences are crucial to understanding the scale and magnitude of this pollutant's influence on watersheds and other natural resources.

Acknowledgements This work was funded by the Duke University Wetland Center Student Research Endowment Fund.

\section{Compliance with Ethical Standards}

Conflicts of Interest The authors declare that they have no conflict of interest.
Disclaimer This manuscript has been reviewed in accordance with the policy of the National Exposure Research Laboratory, US Environmental Protection Agency, and approved for publication. Approval does not signify that contents necessarily reflect views and policies of the Agency, nor does mention of trade names or commercial products constitute endorsement or recommendation for use.

\section{References}

Batty, L., Hooley, D., \& Younger, P. (2008). Iron and manganese removal in wetland treatment systems: rates, processes and implications for management. Science of the Total Environment., 394, 1-8. doi:10.1016/j.scitotenv.2008.01.002.

Bhatia, M., \& Goyal, D. (2014). Analyzing remediation potential of wastewater through wetland plants: a review. Environmental Progress \& Sustainable Energy, 33, 9-27. doi:10.1002/ep.11822.

Brodie, G. A. Constructed wetlands for treating acid drainage at Tennessee Valley Authority coal facilities. Proceeding of the International Conference on the Use of Constructed Wetlands in Water Pollution Control, 461-470 (1990).

Carlson, C. L., \& Adriano, D. C. (1993). Environmental impacts of coal combustion residues. Journal of Environmental Quality, 22, 227-247. doi:10.2134 /jeq1993.00472425002200020002x.

Cherry, D. S., \& Guthrie, R. K. (1977). Toxic metals in surface waters from coal ash. Water Resources Bulletin, 13, 12271236.

Chou, C. L. (2012). Sulfur in coals: a review of geochemistry and origins. International Journal of Coal Geology, 100, 1-13. doi:10.1016/j.coal.2012.05.009.

R Core Team. (2015). $R$ : a language and environment for statistical computing. Vienna: R Foundation for Statistical Computing https://www.R-project.org/.

Dellantonio, A., Fitz, W. J., Repmann, F., \& Wenzel, W. W. (2010). Disposal of coal combustion residues in terrestrial systems: contamination and risk management. Journal of Environmental Quality, 39, 761-775. doi:10.2134 /jeq2009.0068.

Dorman, L., Castle, J. W., \& Rodgers Jr., J. H. (2009). Performance of a pilot-scale constructed wetland system for treating simulated ash basin water. Chemosphere, 75, 939947. doi:10.1016/j.chemosphere.2009.01.012.

Griffin, R. A., \& Jurinak, J. J. (1973). Estimation of activity coefficients from the electrical conductivity of natural aquatic systems and soil extracts. Soil Science, 166, 26-30.

Hallberg, K. B., \& Johnson, D. B. (2005). Biological manganese removal from acid mine drainage in constructed wetlands and prototype bioreactors. Science of the Total Environment, 338, 115-124. doi:10.1016/j.scitotenv.2004.09.011.

Hansen, T. H., de Bang, T. C., Laursen, K. H., Pedas, P., Husted, S., \& Schjoerring, J. K. (2013). Multielement plant tissue analysis using ICP spectrometry. Methods in Molecular Biology, 953, 121-141. doi:10.1007/978-1-62703-152-3_8. 
Izquierdo, M., \& Querol, X. (2012). Leaching behaviour of elements from coal combustion fly ash: an overview. International Journal of Coal Geology, 94, 54-66. doi:10.1016/j.coal.2011.10.006.

Lemly, A. D. (2015). Damage cost of the Dan River coal ash spill. Environmental Pollution, 197, 55-61. doi:10.1016/j. envpol.2014.11.027.

Lemly, A. D., \& Skorupa, J. P. (2012). Wildlife and the coal waste policy debate: proposed rules for coal waste disposal ignore lessons from 45 years of wildlife poisoning. Environmental Science \& Technology, 46, 8595-8600. doi:10.1021 /es301467q.

Lian, J. J., Xu, S. G., Zhang, Y. M., \& Han, W. (2013). Molybdenum(VI) removal by using constructed wetlands with different filter media and plants. Water Science and Technology, 67(8), 1859-1866.

Mackova, M., Dowling, D., \& Macek, T. (2006). Phytoremediation and rhizoremediation (p. 61). Dordrecht: Springer.

Maine, M. A., Sune, N., Hadad, H., Sanchez, G., \& Bonetto, C. (2009). Influence of vegetation on the removal of heavy metals and nutrients in a constructed wetland. Journal of Environmental Management, 90, 355-363.

Michaud, S. C., \& Richardson, C. J. (1989). Relative radial oxygen loss in five wetland plants. In D. A. Hammer (Ed.), Constructed wetlands for wastewater treatment: municipal, industrial and agricultural (pp. 501-507). Chelsea: Lewis Publishers.

Mitsch, W. J., \& Gosselink, J. G. (2015). Wetlands (5th ed.pp. 647-648). Hoboken: Wiley.

Pohlert, T. The pairwise multiple comparison of mean ranks package (PMCMR). R package, http://CRAN.R-project. org/package=PMCMR (2014).

Preussler, K. H., Mahler, C. F., \& Maranho, L. T. (2015). Performance of a system of natural wetlands in leachate of a posttreatment landfill. International journal of Environmental Science and Technology, 12, 2623-2638. doi:10.1007/s13762-014-0674-0.

Richardson, C. J. (1989). Freshwater wetlands: transformers, filters or sinks? In R. R. Sharitz \& J. W. Gibbons (Eds.), Freshwater wetlands and wildlife. Conf-8603101. DOE Symposium Series NO. 61 (pp. 25-46). Oak Ridge: U.S. DOE.

Rowe, C. L. (2014). Bioaccumulation and effects of metals and trace elements from aquatic disposal of coal combustion residues: recent advances and recommendations for further study. Science of the Total Environment, 485-486, 400-406. doi:10.1016/j.scitotenv.2014.03.119.

Rowe, C. L., Kinney, O. M., Fiori, A. P., \& Congdon, J. D. (1996). Oral deformities in tadpoles (Rana catesbeiana) associated with coal ash deposition: effects on grazing ability and growth. Freshwater Biology, 36, 723-730.
Rowe, C. L., Hopkins, W. A., \& Congdon, J. D. (2002). Ecotoxicological implications of aquatic disposal of coal combustion residues in the United States: a review. Environmental Monit. Assess., 80, 207-276. doi:10.1023 /A:1021127120575.

Ruhl, L., Vengosh, A., Dwyer, G. S., Hsu-Kim, H., \& Deonarine, A. (2010). Environmental impacts of the coal ash spill in Kingston, Tennessee: an 18-month survey. Environmental Science and Technology, 44, 9272-9278. doi:10.1021 /es1026739.

Ruhl, L., Vengosh, A., Dwyer, G. S., Hsu-Kim, H., Schwartz, G., Romanski, A., \& Smith, S. D. (2012). The impact of coal combustion residue effluent on water resources: a North Carolina example. Environmental Science \& Technology, 46, 12226-12233. doi:10.1021/es303263x.

Sasaki, K., Ogino, T., Endo, Y., \& Kurosawa, K. (2003). Field study on heavy metal accumulation in a natural wetland receiving acid mine drainage. Materials Transactions, 44, $1877-1884$

Sundberg-Jones, S. E., \& Hassan, S. M. (2007). Macrophyte sorption and bioconcentrations of elements in a pilot constructed wetland for flue gas desulfurization wastewater treatment. Water, Air, and Soil Pollution, 183, 187-200. doi:10.1007/s11270-007-9368-2.

Turker, O. C., Bocuk, H., \& Yakar, A. (2013). The phytoremediation ability of a polyculture constructed wetland to treat boron from mine effluent. Journal of Hazardous Materials, 252-253, 132-141. doi:10.1016/j. jhazmat.2013.02.032.

Vymazal, J. (2013). Emergent plants used in free water surface constructed wetlands: a review. Ecological Engineering, 61P, 582-592. doi:10.1016/j.ecoleng.2013.06.023.

Wickham. (2001). The split-apply-combine strategy for data analysis. Journal of Statistical Software, 40, 1-29.

WCA (2014). "Coal Statistics" World Coal Association. www. worldcoal.org/resources/coal-statistics. Accessed 21 Apr 2015.

Ye, Z. H., Whiting, S. N., Lin, Z. Q., Lytle, C. M., Qian, J. H., \& Terry, N. (2001a). Removal and distribution of iron, manganese, cobalt and nickel within a Pennsylvania constructed wetland treating coal combustion by-product leachate. Journal of Environmental Quality, 30, 1464-1473.

Ye, Z. H., Whiting, S. N., Qian, J. H., Lytle, C. M., Lin, Z. Q., \& Terry, N. (2001b). Trace element removal from coal ash leachate by a 10 -year-old constructed wetland. Journal of Environmental Quality, 30, 1710-1719 http://www.jstatsoft. org/v40/i01/.

Zayed, A., Gowthaman, S., \& Terry, N. (1998). Phytoaccumulation of trace elements by wetlands plants: I. Duckweed. Journal of Environmental Quality, 27, 715-721. doi:10.2134/jeq1998.00472425002700030032x. 